\title{
Response of Mouse Zygotes Treated with Mild Hydrogen Peroxide as a Model to Reveal Novel Mechanisms of Oxidative Stress-Induced Injury in Early Embryos
}

\author{
Diting Qian, Zhiling Li, Yuting Zhang, Yue Huang, Que Wu, Gaizhen Ru, \\ Man Chen, and Bin Wang \\ Reproductive Center, The First Affiliated Hospital of Shantou University Medical College, Shantou University, Shantou, \\ Guangdong, China \\ Correspondence should be addressed to Zhiling Li; stlizhiling@126.com
}

Received 14 April 2016; Revised 18 August 2016; Accepted 31 August 2016

Academic Editor: Gabriele Saretzki

Copyright (C) 2016 Diting Qian et al. This is an open access article distributed under the Creative Commons Attribution License, which permits unrestricted use, distribution, and reproduction in any medium, provided the original work is properly cited.

\begin{abstract}
Our study aimed to develop embryo models to evaluate the impact of oxidative stress on embryo development. Mouse zygotes, which stayed at G1 phase, were treated with prepared culture medium (containing 0.00, 0.01, 0.02, 0.03, 0.04, 0.05, or 0.1 mM hydrogen peroxide $\left(\mathrm{H}_{2} \mathrm{O}_{2}\right)$ ) for $30 \mathrm{~min}$ in experiment 1 . The dose-effects of $\mathrm{H}_{2} \mathrm{O}_{2}$ on embryo development were investigated via comparisons of the formation rate at each stage (2- and 4-cell embryos and blastocysts). Experiment 2 was carried out to compare behaviors of embryos in a mild oxidative-stressed status $\left(0.03 \mathrm{mM} \mathrm{H}_{2} \mathrm{O}_{2}\right)$ with those in a control $\left(0 \mathrm{mM} \mathrm{H}_{2} \mathrm{O}_{2}\right)$. Reactive oxygen species (ROS) levels, variation of mitochondrial membrane potential (MMP), expression of $\gamma \mathrm{H} 2 \mathrm{AX}$, and cell apoptosis rate of blastocyst were detected. We observed a dose-dependent decrease on cleavage and blastocyst rates. Besides, higher level of ROS, rapid reduction of MMP, and the appearance of $\gamma \mathrm{H} 2 \mathrm{AX}$ revealed that embryos are injured early in mild oxidative stress. Additionally, $\gamma \mathrm{H} 2 \mathrm{AX}$ may involve during DNA damage response in early embryos. And the apoptotic rate of blastocyst may significantly increase when DNA damage repair is inadequate. Most importantly, our research provides embryo models to study cell cycle regulation and DNA damage response under condition of different levels of oxidative stress.
\end{abstract}

\section{Introduction}

In aerobic respiration cell, ROS, such as $\mathrm{H}_{2} \mathrm{O}_{2}$, hydroxyl radical $\left({ }^{\circ} \mathrm{OH}\right)$ and superoxide anion radical $\left(\mathrm{O}_{2}{ }^{-}\right)$, appears as a by-products of cell metabolism [1]. Physiological concentration of ROS is necessary to maintain normal embryo development $[2,3]$. However, excessive ROS, produced in improper culture conditions, such as culture systems [4], light conditions [5], and gas atmosphere [1, 6-8], may cause developmental arrest, DNA damage, and cell apoptosis [1]. In many species studied, evidences have been found that ROS compromises embryo development [4-8]. In contrast with gassed bags, incubator chamber is more efficient in generating higher number and better quality of bovine embryos due to a lower level of ROS [4]. Hamster embryos will stop dividing at two-cell stage when zygotes are exposed to cool white fluorescent light [5]. Besides, the number of cleaved embryos is similar when embryos are cultured under $5 \%$ or $20 \% \mathrm{O}_{2}[7,8]$. But there is a decline in the percentage of blastocyst formation $[7,8]$. We can learn that human embryos on day 3 are apparently normal in both groups, but embryo quality is prior in $5 \% \mathrm{O}_{2}[8]$. Those studies revealed that ROSinduced damage correlates with the phenomenon above.

ROS displays roles of double-edged sword in many physiological and pathological processes in cell [9]. It affects embryo development by altering gene expression [1], inducing lipid peroxidation and DNA damage $[1,9]$, containing nuclear and mitochondrial DNA strand breaks $[9,10]$. Numerous studies used $\mathrm{H}_{2} \mathrm{O}_{2}$ to simulate deleterious effects of ROS on embryo development. $\mathrm{H}_{2} \mathrm{O}_{2}$, a form of highly active ROS, readily penetrates the cellular envelope and forms - $\mathrm{OH}$ which is a more active form of ROS. Liu et al. chose an intensive $\left(1 \mathrm{mM} \mathrm{H}_{2} \mathrm{O}_{2}\right.$ for $\left.1.5 \mathrm{~h}\right)$ and a mild $(0.2 \mathrm{mM}$ for $15 \mathrm{~min}$ ) stimulus to treat zygotes (fertilized in vivo); embryos 
from both groups do not divide till 96 hpi [11]. In another experiment, 2-cell embryos were treated with different doses of $\mathrm{H}_{2} \mathrm{O}_{2}(0-50 \mu \mathrm{M})$ for 30 or $60 \mathrm{~min}$; the results showed a negative dose-effect on blastocyst rate [12]. We may observe a decline in blastocyst rate when treating zygotes with $35 \mu \mathrm{M}$ $\mathrm{H}_{2} \mathrm{O}_{2}$ for 15 min [13]. Researches on embryos injured by ROS are common, but most of their embryos was collected from in vivo fertilization, and/or part of the oxidative stimulus started at a later stage of embryo development. Those are inconsistent with clinical assisted reproductive techniques which eggs fertilize in vitro and embryos suffer oxidative stress from the very first.

Studies state that accumulation of ROS caused developmental arrest of embryos by altering activities and structures of mitochondria $[10,11,14]$. Firstly, alteration of mitochondria is an early event in the process of oxidative damage [11]. Secondly, mild oxidative stress may induce a decline in MMP and dysfunction of mitochondria. Then cell cycle arrest and programmed cell death follow [10, 11, 15]. Lastly, mitochondria play an important role in mediating embryo development and apoptosis in oxidative status [10]. Thus, we regard decrease of MMP as an indicator of mitochondrial damage and the early phase of apoptosis.

Another important inducement of embryo developmental retardation is DNA damage. Our previous studies found that $\gamma \mathrm{H} 2 \mathrm{AX}$, the marker of DNA damage [16-18], appeared at 1- and 4-cell embryos fertilized with $\mathrm{H}_{2} \mathrm{O}_{2}$-treated sperm [19]. Further experiments revealed that oxidative stress in sperm activated G2/M delay by cascade of ATM $\rightarrow$ Chk1 $\rightarrow$ Cdc25B/Cdc25C to repair damaged DNA [19-21]. It has been identified that damage response checkpoints include G1/S, intra-S, and G2/M [22]. Cell cycle delay gains time for DNA repair. Besides, $\gamma \mathrm{H} 2 \mathrm{AX}$ provides other molecules such as ATM, Rad 50, and Rad 51 with a recognition site to activate DNA damage response [16-18, 23]. Those molecules are key to repair DNA damage. But specific molecular mechanisms of developmental delay in embryos with oxidative-stressed damage are obscure. Also, cell cycle checkpoint and apoptosis share some common molecules [24]. To some extent, cells will end with death if DNA damage does not repair [25].

The phenomenon above pushes us to research the molecular mechanisms of developmental retardation in zygotes with oxidative-stressed damage. Because of the limitation of clinical researches on human embryos, we treated mouse zygotes with different doses of exogenous $\mathrm{H}_{2} \mathrm{O}_{2}$ to simulate effects of oxidative stress on embryonic development. In order to clarify the molecular mechanisms of DNA damage response activated by oxidative stress and cell cycle arrest in early embryos in subsequent experiment, we aim to develop alternative embryo models with oxidative damage in this research.

\section{Materials and Methods}

2.1. Animals. Adult Kun-Ming mice (3-6 weeks old) were purchased from the Animal Center of Shantou University Medical College and treated in compliance with the Guide for the Care of Use of Laboratory Animal by the US National
Institutes of Health (NIH Publication number 85-23, revised 1996) and the rules of the National Animal Protection of China. All experimental protocols were approved by the Laboratory Animal Ethics Committee of our institution (SUMC2014-014). This study was approved by the Institutional Animal Care and Use Committee of Shantou University Medical College.

2.2. Reagents and Media. All reagents were purchased from Sigma (St. Louis, MO, USA) unless otherwise stated. Rabbit antibody for anti-phospho-histone H2AX ( $\gamma \mathrm{H} 2 \mathrm{AX}$; Ser 139) and goat anti-rabbit Alexa Fluor 488 secondary antibody were from Abcam (England). The In Situ Cell Death Detection kit (Fluorescein) was from Roche (Switzerland). PI and DAPI were from Panera (France). Human tubal fluidHEPES (HTF-HEPES) was from Cooper Surgical (USA). Phosphate-buffered saline (PBS) was dissolved in MilliQ water: $136.9 \mathrm{mM} \mathrm{NaCl}, 2.7 \mathrm{mM} \mathrm{KCl}, 0.9 \mathrm{mM} \mathrm{CaCl}_{2}$, $0.5 \mathrm{mM} \mathrm{MgCl}_{2}, 7 \mathrm{mM} \mathrm{Na}_{2} \mathrm{HPO}_{4}, 1.25 \mathrm{mM} \mathrm{NaH}_{2} \mathrm{PO}_{4}, 1.5 \mathrm{mM}$ $\mathrm{KH}_{2} \mathrm{PO}_{4}$, and $1 \mathrm{~g} / \mathrm{L}$ PVA (290 mOsm/kg; pH 7.2). Pancreatin solution was diluted to $0.1 \%$ with $\mathrm{PBS}$, the $\mathrm{pH}$ adjusted to 3.0 with $\mathrm{HCl}$, filtered, aliquoted, and stored at $4^{\circ} \mathrm{C}$. The embryo culture medium was made by adding $0.4 \%$ BSA and $10 \%$ fetal bovine serum to HTF solution. And the medium of the treated group was made by addition of $\mathrm{H}_{2} \mathrm{O}_{2}$ to a final concentration of $0.01,0.02,0.03,0.04,0.05$, or $0.1 \mathrm{mM}$ and then preequilibrated them for 1 hour before use. Stationary liquid was $4 \%$ paraformaldehyde in PBS. Membrane liquid was PBS $+0.5 \%$ Triton X-100. Sperm capacitation liquid (HTF solution $+1.5 \%$ bovine serum albumin), fertilization liquid (HTF solution $+0.4 \%$ BSA), and embryo culture medium were placed at $37^{\circ} \mathrm{C}$ in a $5 \% \mathrm{CO}_{2}$ incubator for $4 \mathrm{~h}$. Blastocysts were cultured in blastocyst medium (Cooper Surgical, Inc.).

2.3. Epididymal Sperm Preparation, Collection, and Culture of Oocytes and Embryos. As described in our previous study, sperm was obtained from the tail of the epididymis of mature male mice and incubated in capacitation medium at $37^{\circ} \mathrm{C}$ in a $5 \% \mathrm{CO}_{2}$ incubator for $1 \mathrm{~h} \mathrm{[19].} \mathrm{Female} \mathrm{mice} \mathrm{were}$ intraperitoneally injected with consecutive injections of $10 \mathrm{IU}$ pregnant mare serum gonadotropin (PMSG) to promote ovulation. And 10 IU human chorionic gonadotropin (HCG) $48 \mathrm{~h}$ apart. Then mice were euthanized by cervical dislocation at 13 to $15 \mathrm{~h}$ after HCG administration. Cumulus oocytes were collected from the ovaries of the mice, placed in $37^{\circ} \mathrm{C}$ $\mathrm{PBS}$, then moved to $37^{\circ} \mathrm{C}$ fertilization liquid containing $10 \mu \mathrm{L}$ capacitated sperm, and incubated for $6 \mathrm{~h}$ to permit fertilization. Zygotes were washed three times and cultured in new medium after fertilization.

2.4. Experiment 1: Effects of Zygotes Oxidative Stress on Embryonic Development. According to studies by Liu et al. [11] and our preliminary experiments, zygotes $(7 \mathrm{hpi})$ were placed in culture medium with different concentrations of $\mathrm{H}_{2} \mathrm{O}_{2}$ for 30 minutes, then rinsed three times, and cultured in medium without $\mathrm{H}_{2} \mathrm{O}_{2}$. Embryos were incubated at $37^{\circ} \mathrm{C}$ in a $5 \% \mathrm{CO}_{2}$ atmosphere. The medium was renewed daily. Development of two-cell and four-cell embryos and blastocysts 
was observed, respectively, at $24 \mathrm{hpi}, 48 \mathrm{hpi}$, and $96 \mathrm{hpi}$ with an inverted microscope (Olympus Inc., Japan). Cleavage and blastocyst formation rates were defined as the total number of embryos from corresponding stage divided by total number of zygotes. The total number of zygotes included in 0.01, 0.02, $0.03,0.04,0.05$, and $0.1 \mathrm{mM} \mathrm{H}_{2} \mathrm{O}_{2}$ was $519,363,316,489,365$, 326 , and 50, respectively.

\subsection{Experiment 2: Effects of Oxidative Stress Induction on Embryo Injured Related Variables}

2.5.1. Determination of ROS Products. The intracellular ROS level was detected by $2^{\prime}, 7^{\prime}$-dichlorofluorescein fluorescence (DCFH-DA). A stock solution of DCFH-DA $\left(1 \times 10^{-3} \mathrm{~mol} / \mathrm{L}\right.$ in DMSO) was added to the embryo culture medium to a final concentration of $10 \mu \mathrm{mol} / \mathrm{L}$, and zygotes were incubated at $37^{\circ} \mathrm{C}$ in $5 \% \mathrm{CO}_{2}$ for 30 minutes. Embryos were rinsed three times ( $5 \mathrm{~min}$ each time) in fresh culture fluid to remove the residual dye and then placed on a glass slide with $20 \mu \mathrm{L}$ culture fluid. Fluorescence staining was observed immediately under a fluorescence microscope with exciting light of $495 \mathrm{~nm}$ and emissive light of $520 \mathrm{~nm}$ (Nikon Eclipse $90 \mathrm{Ni}-\mathrm{E})$. The fluorescence intensity was recorded at $5 \mathrm{~s}$ after exciting the zygotes. Image Pro Plus 6.0 was used to quantify the fluorescence (Media Cybernetics Inc., Bethesda, MD, USA). 34 zygotes from the treated group and 29 zygotes from the untreated group were detected in this part.

\subsubsection{Detection of Mitochondrial Membrane Potential (MMP).} MMP was detected at 1-cell embryos with the lipophilic, cationic probe $5,5^{\prime}, 6,6^{\prime}$-tetrachloro-1, $1^{\prime} 3,3^{\prime}$-tetraethylbenzimidazolylcarbocyanine iodide (JC-1, stock $5 \mathrm{mg} / \mathrm{mL}$ ). Then, PBS was added to the solution of JC-1 to a final concentration of $1.25 \mu \mathrm{mol} / \mathrm{L}$. Zygotes were washed three times with PBS (5 min each time) after staining for $20 \mathrm{~min}$ and placed on a glass slide. Images were recorded immediately by using a fluorescent microscope (Nikon Eclipse $90 \mathrm{Ni}$ E) at an excitation wavelength of $488 \mathrm{~nm}$ and beam path control setting at LP $585 \mathrm{~nm}$ for Chl and BP 505-530 nm for Ch2. Analysis of data was done with Image Pro Plus 6.0 software (Media Cybernetics Inc., Bethesda, MD, USA). The number of treated and untreated zygotes at each hour was shown as follows: 18 and 20 for $0 \mathrm{~h}, 17$ and 25 for $1 \mathrm{~h}$, 22 and 19 for $2 \mathrm{~h}, 22$ and 21 for $4 \mathrm{~h}$, and 19 and 16 for $6 \mathrm{~h}$.

2.5.3. Assay of $\gamma H 2 A X$. Embryos were rinsed with TPBS $(\mathrm{PBS}+0.05 \%$ Tween 20$)$, and zona pellucidae were removed from embryos with pancreatin $(0.1 \%)$ for $30 \mathrm{~s}$. Then embryos were fixed with $4 \%$ paraformaldehyde in TPBS for $30 \mathrm{~min}$, permeabilized at room temperature for $30 \mathrm{~min}$, and blocked for $1 \mathrm{~h}$ at room temperature in blocking solution (PBS + $0.05 \%$ Tween $20+3 \%$ BSA $+10 \%$ normal goat serum). Before each step, embryos were washed with TPBS three times, 5 minutes per time. After blocking, embryos were incubated with rabbit anti- $\gamma \mathrm{H} 2 \mathrm{AX}$ primary antibody $(1: 1000$ dilution) for $12 \mathrm{~h}$ to $15 \mathrm{~h}$ at $4^{\circ} \mathrm{C}$, then washed, and incubated with goat anti-rabbit Alexa Fluor 488 secondary antibody (1:500 dilution). The immunostained embryos were washed with TPBS, counterstained with propidium iodide, and observed under a fluorescence microscope (Nikon Eclipse $90 \mathrm{Ni}-\mathrm{E})$.

2.5.4. TUNEL Assay. TUNEL assay was performed to analyze apoptosis of blastocysts, using the In Situ Cell Death Detection kit (fluorescein) in accordance with manufacturer's instructions. Embryos were withdrawn at 96 hpi to collect blastocysts according to our previous experiment [20]. Zona pellucidae were removed from the embryos at first. Then embryos were washed three times with TPBS, fixed in $4 \%$ paraformaldehyde at room temperature for $30 \mathrm{~min}$, and mounted on polylysine slides and washed again with TPBS and permeabilized at room temperature for $30 \mathrm{~min}$. Embryos were washed with TPBS three times again and incubated with fluorescein-conjugated dUTP and terminal deoxynucleotidyl transferase at $37^{\circ} \mathrm{C}$ in dark for $1 \mathrm{~h}$. The reaction was terminated by washing in TPBS three times, 5 min each time, and then the embryos were counterstained with DAPI, rinsed with TPBS, and sealed with coverslips. Observation was done under an Olympus FluoView FV 1000 confocal microscope (Olympus Inc., Japan). According to previous studies [20], the apoptotic rate was expressed as the percentage of TUNEL-positive cell number relative to the total cell number of blastocysts. 24 blastocysts from the control group and 34 from the treated group were used for the TUNEL assay.

2.6. Statistical Analysis. Results were collected from at least 3 independent experiments and data were analyzed by SPSS 17.0 software (SPSS Inc., Chicago, IL). Data showed as percentages were analyzed using Chi square test. Values expressed as mean \pm SD of treated and untreated groups was compared, using Student's $t$-test. $P<0.05$ was considered statistically significant.

\section{Results}

3.1. Experiment 1: A Dose-Dependent Decline of Embryonic Development at Each Stage. We could learn from Figure 1(a) that blastocysts have a bigger shape in control group than those in $0.03 \mathrm{mM} \mathrm{H}_{2} \mathrm{O}_{2}$ group. And we characterized the dose-response of $\mathrm{H}_{2} \mathrm{O}_{2}$ on embryo development. No zygotes divided at $60 \mathrm{hpi}$ when they were treated with $0.1 \mathrm{mM} \mathrm{H}_{2} \mathrm{O}_{2}$. $\mathrm{H}_{2} \mathrm{O}_{2}$ at $0.01 \mathrm{mM}$ or $0.02 \mathrm{mM}$ had no significant effects on the percentages of two- and four-cell embryos or blastocyst formation at 24, 48, and $96 \mathrm{hpi}$, respectively (Figure 1(b)) while $\mathrm{H}_{2} \mathrm{O}_{2}$ at $0.03 \mathrm{mM}$ exposure produced a $14.50 \%$ reduction in blastocyst formation rate $(P<0.05$, Figure $1(\mathrm{~b}))$. Although the two- and four-cell embryo formation rates were not different from the control group, $0.03 \mathrm{mM} \mathrm{H}_{2} \mathrm{O}_{2}$ was the concentration of our treated group in subsequent experiments. When mouse zygotes were exposed to $\mathrm{H}_{2} \mathrm{O}_{2}$ at $0.04 \mathrm{mM}$ or $0.05 \mathrm{mM}$, the proportion of blastocyst formation and cleavage rates decreased $(P<0.05$, Figure $1(\mathrm{~b}))$ and exhibited a dosedependent decline (Figure 1(b)). 

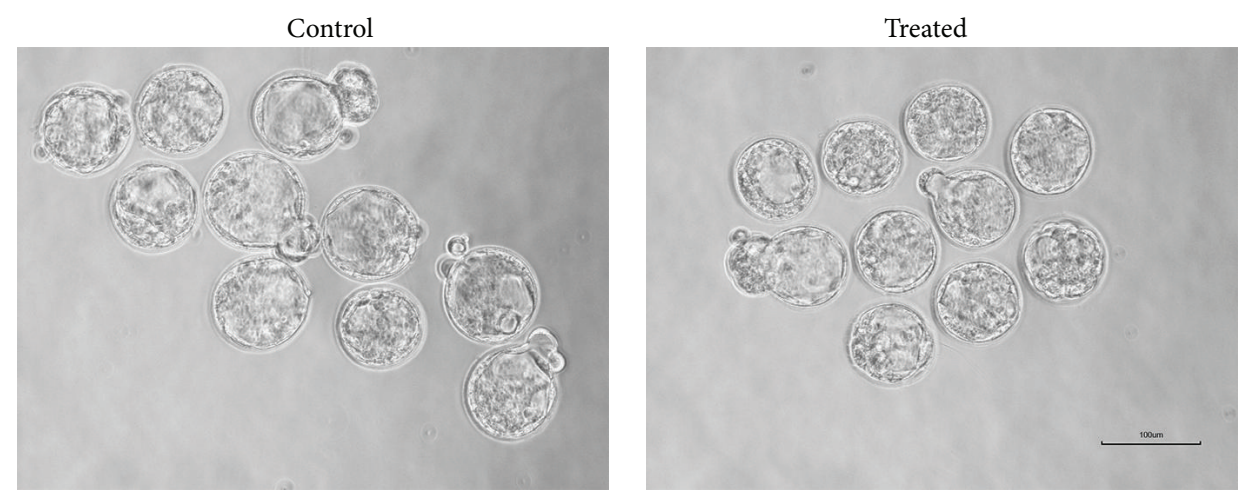

(a)

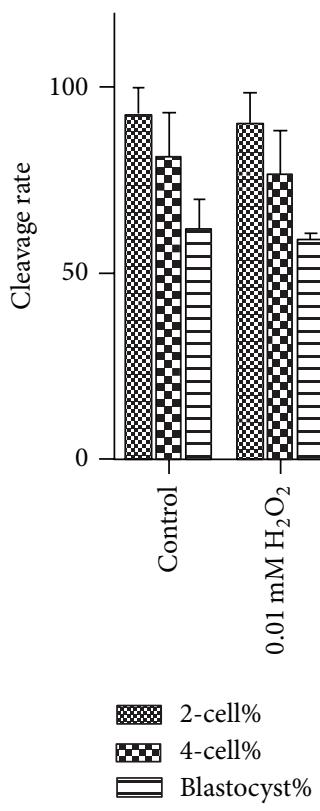

(b)

FiguRE 1: Comparisons of embryo development between zygotes from groups with different concentration of $\mathrm{H}_{2} \mathrm{O}_{2}$ and control group. (a) Representative images of embryos at $96 \mathrm{hpi}$ from control group and $0.03 \mathrm{mM} \mathrm{H} \mathrm{O}_{2}$ group. (b) Counting out the cleavage rates from each group, blastocyst formation rate declined from $0.03 \mathrm{mM} \mathrm{H}_{2} \mathrm{O}_{2}$ group; early embryos showed stagnation from $0.04 \mathrm{mM} \mathrm{H}_{2} \mathrm{O}_{2}$ group. Data are presented as mean $\pm \mathrm{SD}$ in six independent experiments for each group at least. Differences between the groups were calculated using Chi square test. ${ }^{*} P<0.05 ;{ }^{* *} P<0.01 ;{ }^{* * *} P<0.001$ compared with the control group.

\subsection{Experiment 2: Oxidative Stress Implies the Variations in Embryos}

3.2.1. ROS Concentrations in Embryos. The comparison of the yields of ROS between treated and untreated group was via DCFH-DA fluorescence intensity in zygotes ( $7.5 \mathrm{hpi}$ ) (Figure 2(a)). The mean fluorescence intensity of ROS in zygotes of the treated group $(23.01 \pm 1.47)$ was about 2 -fold higher than that in the control group $(12.19 \pm 3.44)(P<0.05$, Figure 2(b)).

3.2.2. Change in MMP of Zygotes with Time. To further characterize the harmful effects of mild oxidative stress on embryo development in vitro, we detected the variation of MMP after treatment of zygotes with $0.03 \mathrm{mM} \mathrm{H}_{2} \mathrm{O}_{2}$ at $0,1,2,4$, and $6 \mathrm{~h}$. The MMP was higher in control group than treated group at all check points (Figure 3(a)). The relative ratio of red to green fluorescence intensity indicated that MMP dropped rapidly within the first hour and did not recover within 6 hours after treatment $(P<0.05$, Figure $3(\mathrm{~b}))$. That is to say, the relative pixel ratio intensity, which reflected the MMP, was lower in $\mathrm{H}_{2} \mathrm{O}_{2}$-treated zygotes within $1 \mathrm{~h}$ after the treatment of $\mathrm{H}_{2} \mathrm{O}_{2}$ compared with the control group.

3.2.3. Expression of $\gamma H 2 A X$ in Embryos with Oxidative Stress Injury. We discovered that $\mathrm{H}_{2} \mathrm{O}_{2}$-treated embryos expressed $\gamma \mathrm{H} 2 \mathrm{AX}$ at the one-, two-, and four-cell embryos. However, there is no $\gamma \mathrm{H} 2 \mathrm{AX}$ staining in control group (Figures 4(a) and 4(b)). Therefore, DNA damage existed in one-, two-, and four-cell embryos that developed from oxidative damaged zygotes. Representative images are shown in Figures 4(a) and $4(\mathrm{~b})$. 

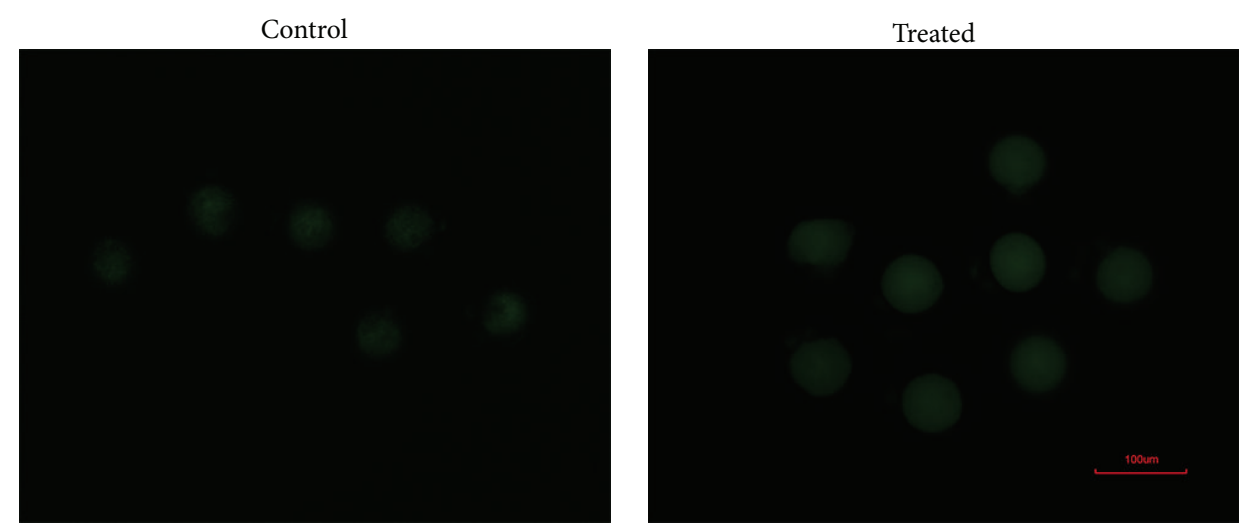

(a)

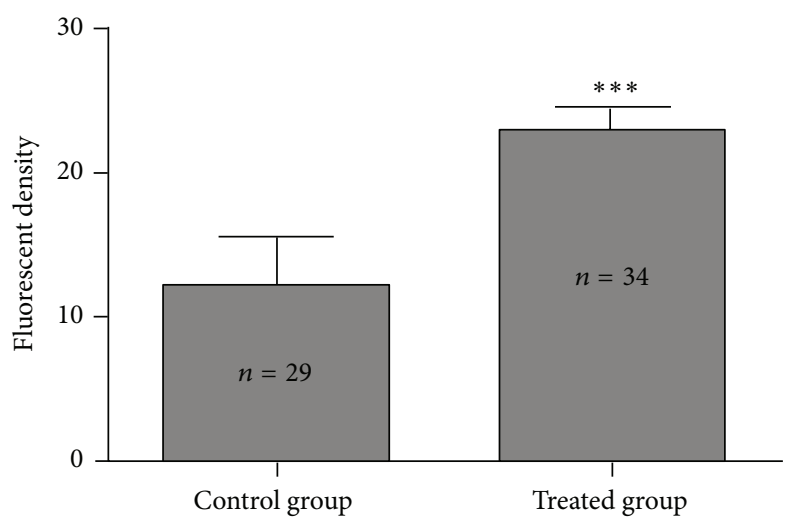

(b)

FiguRE 2: Comparisons of ROS levels between control group and $\mathrm{H}_{2} \mathrm{O}_{2}$ treated group. (a) Representative pictures of ROS levels. (b) Average fluorescence intensity per zygote. Data are showed as mean \pm SD, collected from three independent experiments, and each experiment had 5 zygotes at least. $n$ shows the number of zygotes. ${ }^{* * *} P<0.001$, the treated group compared with the untreated group (Student's $t$-test).

3.2.4. Apoptosis of Blastocysts. The average cell number per blastocyst in the treated group was $37.77 \pm 3.94$ and $46.74 \pm$ 3.05 in the control group $(P<0.05)$. At the same time, the average apoptotic cell counts was over 2 -fold higher in the treated group relative to the untreated group $(6.24 \pm 2.42$ (treated) versus $2.27 \pm 0.70$ (control) $)(P<0.05)$. Moreover, the mean apoptotic rate was $(15.9 \pm 5.8) \%$ for each $\mathrm{H}_{2} \mathrm{O}_{2}$ treated embryo versus $(4.9 \pm 1.3) \%$ for the control. Representative images of normal and apoptotic mouse blastocysts are illustrated in Figure 5.

\section{Discussion}

Embryos cultured in vitro are subjected to oxidative stress. We used $\mathrm{H}_{2} \mathrm{O}_{2}$ to mimic oxidative stress. Finally, we gain a series of embryo models which suffer different levels of oxidative stress. And we found that a slightly high level of ROS could lead to a low formation rate of blastocyst with less cells by reducing MMP of zygotes and increasing DNA damage at one-, two-, and four-cell embryos.

Bain and colleagues reported that effects of $\mathrm{H}_{2} \mathrm{O}_{2}$ on blastocyst formation became more severe during the treatment of later stages of development [26]. Another important factor is embryos subjecting to oxidative stress from early stage in clinic. Thus, we chose zygotes rather than 2- or 4cell embryos to be treated to avoid excessively adverse effects on embryos. Ciray et al. and Kasterstein et al. have shown that embryos in clinic ( $5 \%$ or $20 \% \mathrm{O}_{2}$ concentration) have a similar cleavage rate at day 3 but decreasing blastocyst formation rate at day 5 or 6 in $20 \% \mathrm{O}_{2}$ atmosphere $[7,8]$. So we use small concentration gradient $(0-0.1 \mathrm{mM})$ and low doses of $\mathrm{H}_{2} \mathrm{O}_{2}$ to treat zygotes for 30 minutes according to our preliminary experiment and other researches [10, 11, 13, 26], just for embryo model with similar developmental pattern above. Furthermore, cells undergoing G1 $\rightarrow$ S transition are very sensitive to low levels of stimulus [22]. Many embryos under oxidative stress step into a transient cell cycle arrest which is activated by DNA damage response before apoptosis [11]. In order to gain a suitable model to research molecular mechanisms about DNA damage repair, cell cycle, and apoptosis in our subsequent experiments, we utilized $\mathrm{H}_{2} \mathrm{O}_{2}$ to treat zygotes at $7 \mathrm{hpi}$ as they are in G1 phase [20], which is the first checkpoint of cell cycle to keep genetic stability. Also, that may provide models for us to study molecular mechanisms which activate G2/M phase delay.

Based on the theory above, we implemented experiment 1 and the results showed that zygotes presented no division in $0.1 \mathrm{mM} \mathrm{H}_{2} \mathrm{O}_{2}$ at $60 \mathrm{hpi}$. And there will be a lower percentage 

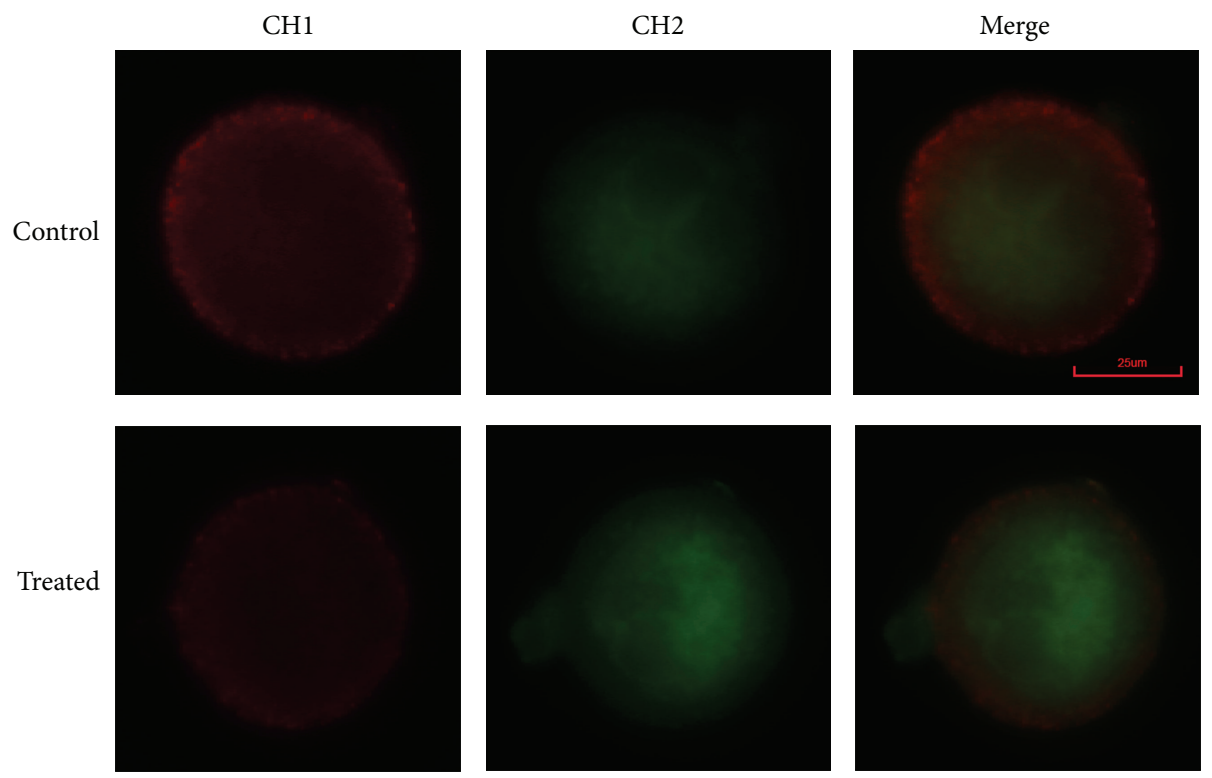

(a)

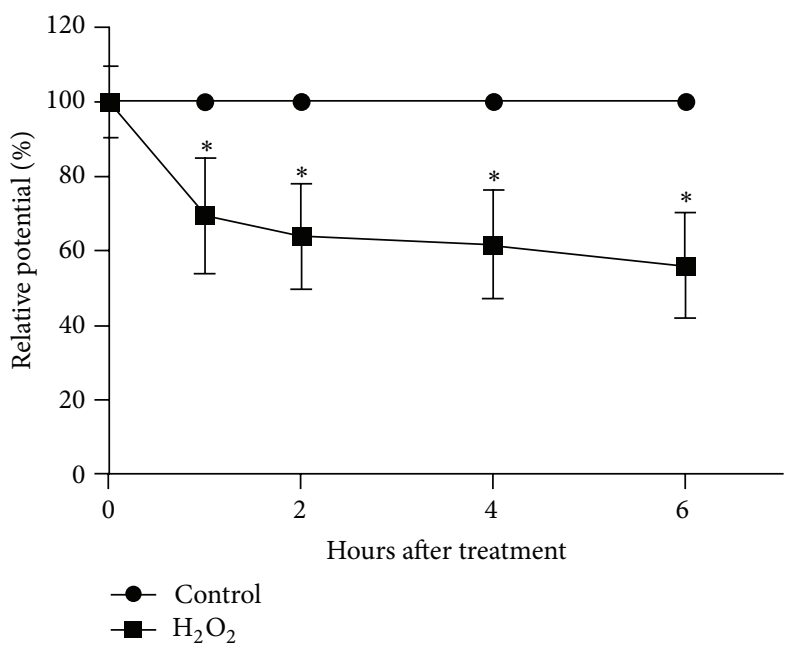

(b)

FIGURE 3: Dysfunction of mitochondria in mouse zygotes induced by $\mathrm{H}_{2} \mathrm{O}_{2}$. (a) Representative images of MMP in mouse zygotes at $6 \mathrm{~h}$ from treated group and control group; red fluorescence from channel 1 represented J-aggregates (high polarized mitochondria); green fluorescence from channel 2 represented monomer form of JC-1 (low polarized mitochondria). (b) The analysis of MMP was via the comparisons of relative fluorescence intensity and set the average value of red/green fluorescence intensity at each time point from control group as $100 \%$; MMP in treated group was showed relative to control group at the corresponding point time. MMP in treated zygotes declined during the first hour after treatment by $0.03 \mathrm{mM} \mathrm{H}_{2} \mathrm{O}_{2}$ for $30 \mathrm{~min}$ and kept on dropping over the subsequent hours. Data are presented as mean $\pm \mathrm{SD}$ in three independent experiments. ${ }^{*} P<0.05$, the treated group versus the control group (Student's $t$-test).

of embryo formation rate at each stage with treatment of a higher concentration of $\mathrm{H}_{2} \mathrm{O}_{2}$. To put it another way, embryo developmental patterns in $0.01-0.05 \mathrm{mM} \mathrm{H}_{2} \mathrm{O}_{2}$ could be used, as alternate models, to research influences of mild oxidative stress on developmental retardation. Developmental conditions of 0.01 or $0.02 \mathrm{mM} \mathrm{H}_{2} \mathrm{O}_{2}$ group could be used to study embryo development by Peng et al. No obvious differences were found in cleavage or high quality embryo rate at day 3 [27]. Moreover, the embryo model in 0.04 or $0.05 \mathrm{mM} \mathrm{H}_{2} \mathrm{O}_{2}$ group may suit studying the human embryo development with low formation rate at day 3 and day 5 or 6 [28]. Most importantly, we selected $0.03 \mathrm{mM} \mathrm{H}_{2} \mathrm{O}_{2}$ in our subsequent studies as we found the developmental style was similar to clinic and other researches [7, 8]. That is, there are no obvious differences in the percentage of cleavage rates between $20 \%$ and $5 \% \mathrm{O}_{2}$ concentration, but $5 \% \mathrm{O}_{2}$ group have more top-quality embryos on day 3 and more blastocysts on day 5 or $6[7,8]$. Our data presented that embryo formation rates at $24 \mathrm{~h}$ and $48 \mathrm{~h}$ were approximate, but more blastocysts with less apoptotic cells were in control group than $0.03 \mathrm{mM} \mathrm{H}_{2} \mathrm{O}_{2}$. The concurrent research found $\mathrm{G} 2 / \mathrm{M}$ delay of zygotes in $0.03 \mathrm{mM} \mathrm{H}_{2} \mathrm{O}_{2}$ group [29]. As is 


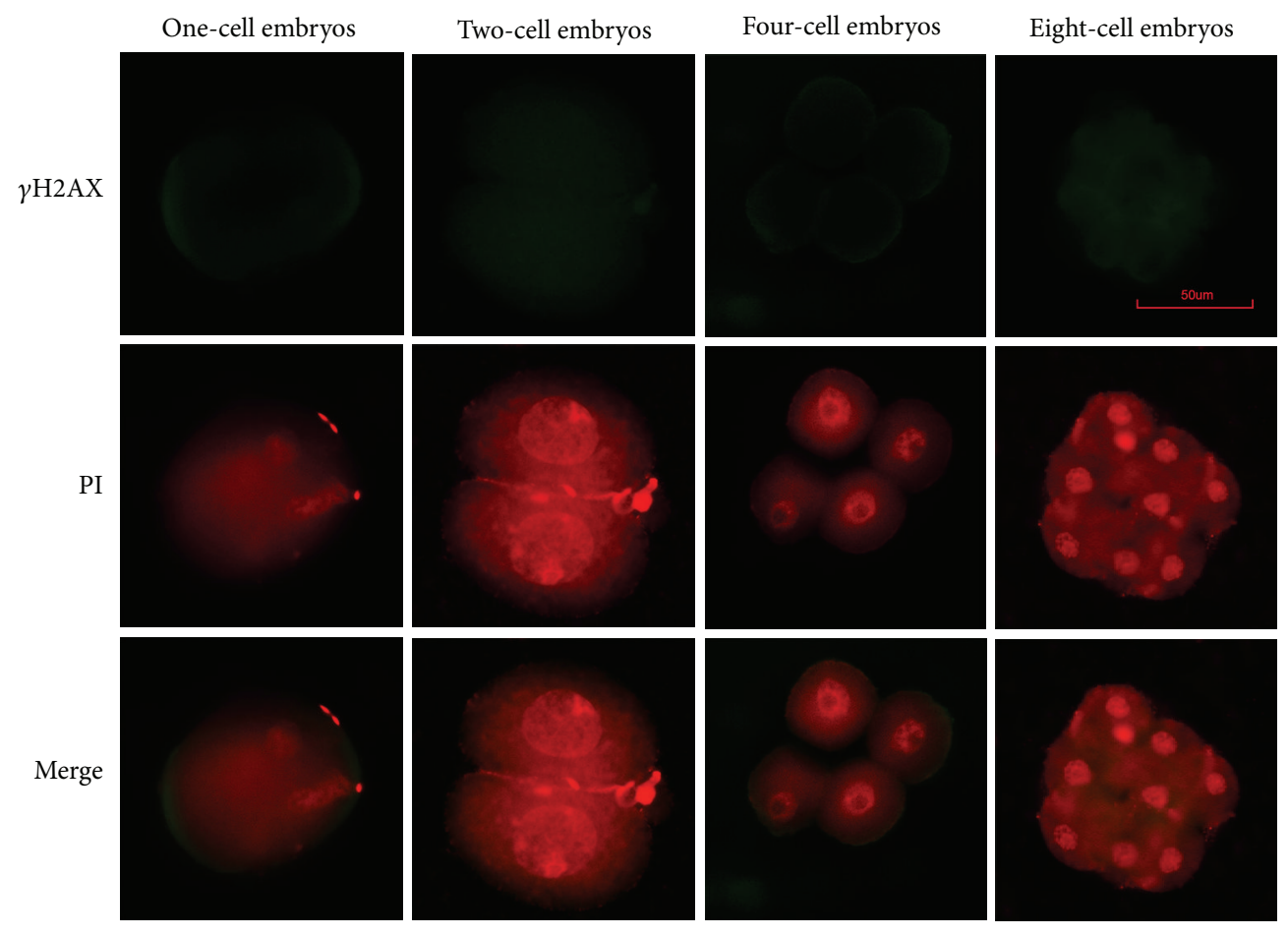

(a)

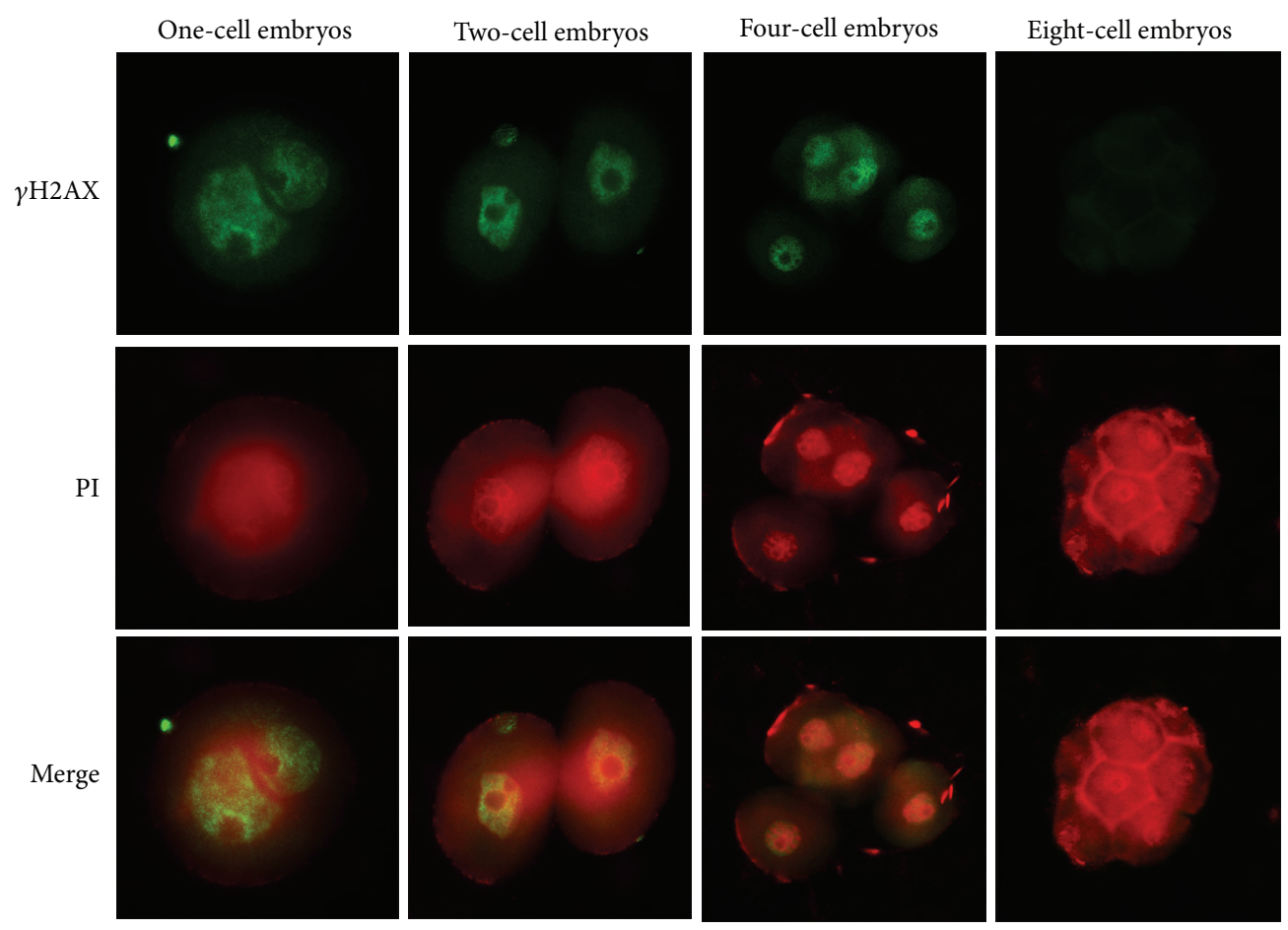

(b)

Figure 4: Expression of $\gamma \mathrm{H} 2 \mathrm{AX}$. (a) Control group; no positive signal. (b) $0.03 \mathrm{mM} \mathrm{H}_{2} \mathrm{O}_{2}$ treated group; positive signal at one-, two- and four-cell stages. $\mathrm{PI}=$ propidium iodide staining. 

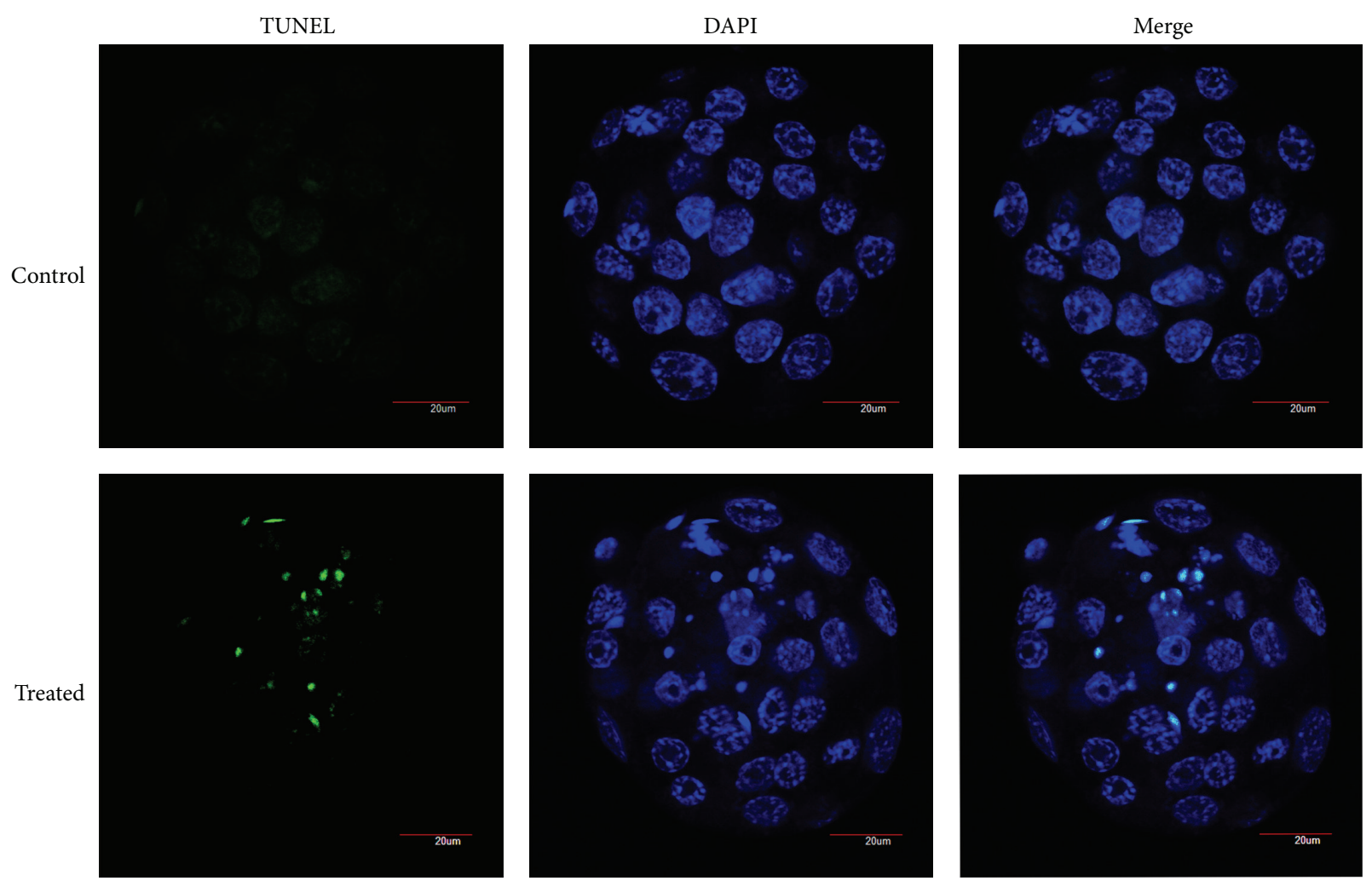

FIGURE 5: Hydrogen peroxide-induced apoptosis. Representative images of normal and apoptotic cells in mouse blastocysts; no positive signals (Green stains) appeared in control group; several positive signals could be seen in treated group. Nuclei were stained with DAPI (blue).

known human embryos at 4- to 8-cell and mouse embryos at 1- to 2-cell are undergoing ZGA (zygotic gene activation) phase, which is a key process of maternal to zygotic transition $[29,30]$. Embryos develop the ability to support proper development of early stage during ZGA phase [30]. The above prompt is that potential damage may exist in early mouse embryos (1- and/or 2-cell embryos) in $0.03 \mathrm{mM} \mathrm{H}_{2} \mathrm{O}_{2}$ group and it may be adverse to the formation of blastocyst. Further investigations will be done to determine the molecular mechanisms about cell cycle arrest. As to reasons for the otherness of human embryo development aforementioned, it may be the inconsistent ovulation induction protocols, different lab conditions, technologist's experiences, technologies and skills, and many other uncontrollable factors. Additionally, we have observed that the shape of embryos in control group is larger than that of the treated group and that outcome may be induced by high apoptotic rate in blastocyst of treated group. Nevertheless, it needs more endeavor to unveil the influences of the above phenomenon on blastocyst quality. Our results showed a higher production of intracellular ROS (Figure 2(b)) which indicates that embryos are in oxidative stress status. Moreover, we could draw a conclusion from the sharp decline of MMP that zygotes were damaged during $1 \mathrm{~h}$ after treated by $0.03 \mathrm{mM} \mathrm{H} \mathrm{O}_{2}$. Embryos with continuous high MMP can reactive the arrest development [31]. Thus, embryos may be damaged by ROS at the first hour after treatment by $0.03 \mathrm{mM} \mathrm{H}_{2} \mathrm{O}_{2}$.
Our previous study revealed that development of zygotes from fresh spermatozoa and sperm treated with $1 \mathrm{mM} \mathrm{H}_{2} \mathrm{O}_{2}$ for $1 \mathrm{~h}$ was similar [19]. But blastocyst formation rate was significantly declined when treating zygotes with lower concentration of $\mathrm{H}_{2} \mathrm{O}_{2}$ and shorter processing time. It states that oxidative-stressed damage put more negative influences on zygotes than on sperm. And the reasons might be as follows: (1) two pronuclei were exposed to oxidative stress and both might be damaged; (2) embryonic cytoplasm was affected by ROS, especially mitochondria. Almost the whole cytoplasm is from oocyte and cytoplasm plays a major role in regulating early embryo development [10]. That finding further suggests that maternal resources are crucial in mediating early embryo development which conforms to other researches $[29,30]$.

To further delineate the effects of oxidative stress on DNA, we firstly detected the expression of $\gamma \mathrm{H} 2 \mathrm{AX}$. Our results showed that $\gamma \mathrm{H} 2 \mathrm{AX}$ appeared at the one-, two-, and four-cell embryos in the treated group. Luo et al. found that mouse embryos exposed to $50-\mathrm{Hz}$ sinusoidal electromagnetic fields (EMFs) for $24 \mathrm{~h}$ elicited the presence of $\gamma \mathrm{H} 2 \mathrm{AX}$ foci in two-cell embryos or $\gamma \mathrm{H} 2 \mathrm{AX}$ expressed in two- and eight-cell embryos with exposure for $48 \mathrm{~h}$ [32]. UV irradiation caused expression of $\gamma \mathrm{H} 2 \mathrm{AX}$ at later embryo stage only [33]. Those behaviors of $\gamma \mathrm{H} 2 \mathrm{AX}$ may be induced by various types of DNA damage or embryos diversely in response to different degree of DNA damage. Further investigations are necessary to better unveil that unsolved puzzle. G2/M checkpoint of zygotes 
was delayed at $0.03 \mathrm{mM} \mathrm{H}_{2} \mathrm{O}_{2}$ group as compared with control group [29]. And DNA damage exists in early embryos. There were no significant differences in the percentages of 2and 4-cell embryo formation. One possible reason could be that $\mathrm{G} 2 / \mathrm{M}$ phase is from 17 hpi to 20 hpi in control group [20], but we recorded the cleavage rate at $24 \mathrm{hpi}$, the last 4 hours before recording provide embryos of treated group with time to catch up. Another reason might be that oxidative stress, increasing the metabolism with superoxide detoxification, might accelerate the speed of the first cleavage [26]. Also DNA damage response may play a positive role in repair damaged DNA of early embryos, and it may benefit from the functions of $\gamma \mathrm{H} 2 \mathrm{AX}$ below: firstly, $\gamma \mathrm{H} 2 \mathrm{AX}$ may work as it collects other signal or repair proteins to injured sites $[16,17$, 23]; secondly, it localizes at kinetochores and calls together $\mathrm{MDC1}, \mathrm{MDC} 2$, and CDC20 for assembling an integrated mitotic checkpoint complexes [34]; finally, dynamic $\gamma \mathrm{H} 2 \mathrm{AX}$ in cell cycle reminds us of its specific role in the process of mitosis [18, 35]. Recently, it has been demonstrated that PIk3mediated activation of $\gamma \mathrm{H} 2 \mathrm{AX}$ subsequently regulates the cell cycle progression and cell fate in human corneal epithelial cells [36]. Besides, $\gamma \mathrm{H} 2 \mathrm{AX}$ accumulated beyond its role in DNA damage and as a regulator of cell cycle progression by inhibitor DNA replication $[37,38]$. Those remind us that $\gamma \mathrm{H} 2 \mathrm{AX}$ may involve in DNA damage response to regulate cell cycle in zygotes with oxidative-stress damage, too. We may learn that normal zygotes mediate $\mathrm{G} 2 / \mathrm{M}$ by protein kinase A (PKA), WEE1B, 14-3-3e, and M-phase promoting factors [39-41]. But the specific molecular pathways regulate cell cycle of normal zygotes and zygotes with oxidative-stressed damage are unclear, and whether DNA damage in zygotes activates cascade of ATM $\rightarrow$ Chk1 $\rightarrow$ Cdc25B/Cdc25C during $\mathrm{G} 2 / \mathrm{M}$ to repair the damage depends on our further study. Moreover, compared with our previous study, in which $\gamma \mathrm{H} 2 \mathrm{AX}$ appeared at one- and four-cell stage [19], the above phenomenon verifies that zygotes with oxidative-stressed damage exert more negative effects on embryo development than zygotes derived from ova fertilized with $\mathrm{H}_{2} \mathrm{O}_{2}$-treated sperm again. In the later stage that did not obviously express $\gamma \mathrm{H} 2 \mathrm{AX}$, we assume that damaged cells in those embryos were removed following either apoptosis or permanently developmental arrest or repairing their damaged DNA. Our results illustrated that ROS gives rise to the formation of blastocysts with less cells. Although DNA damage response may produce positive roles at one-, two-, and four-cell embryo stages, the cell counts of blastocyst and the blastocyst formation rate were still significantly lower than the untreated group, indicating that activation of DNA repair mechanisms and/or cell cycle arrest failed to completely repair the damage. Our results strongly state that adverse effects of ROS on embryo development, at least partly, act through DNA damage.

\section{Conclusions}

In brief, effects of oxidative stress on early embryos are dosedependent and lasting to blastocyst. Also, the decline of MMP caused by oxidative stress in zygotes may forecast the compromised development of embryos. $\gamma \mathrm{H} 2 \mathrm{AX}$ may play an important role in DNA repair of early embryo stages, but cells with unrepaired DNA will reduce the blastocyst formation rate. Therefore, our embryo models should be considered when evaluating the hazardous effects of environmental ROS in human embryos and search for effective approaches for prevention.

\section{Competing Interests}

The authors declare that there is no conflict of interests regarding the publication of this paper.

\section{Acknowledgments}

The authors are thankful for the support from Center for Neuroscience, Shantou University Medical College for the utilization of the laser confocal microscopy. Those studies were supported by National Natural Science Foundation of China (nos. 30872771, 81070542, 81471522, and 81671536); Natural Science Foundation of Guangdong Province of China (nos. 8151503102000010, 10151503102000020, and 2014A030313482); Guangdong Provincial Science and Technology Project (2016A020218015).

\section{References}

[1] M. Takahashi, "Oxidative stress and redox regulation on in vitro development of mammalian embryos," The Journal of Reproduction and Development, vol. 58, no. 1, pp. 1-9, 2012.

[2] B. D’Autréaux and M. B. Toledano, "ROS as signalling molecules: mechanisms that generate specificity in ROS homeostasis," Nature Reviews Molecular Cell Biology, vol. 8, no. 10, pp. 813824, 2007.

[3] G. Groeger, C. Quiney, and T. G. Cotter, "Hydrogen peroxide as a cell-survival signaling molecule," Antioxidants \& Redox Signaling, vol. 11, no. 11, pp. 2655-2671, 2009.

[4] M. E. Arias, R. Sanchez, and R. Felmer, "Evaluation of different culture systems with low oxygen tension on the development, quality and oxidative stress-related genes of bovine embryos produced in vitro," Zygote, vol. 20, no. 3, pp. 209-217, 2012.

[5] M. Takenaka, T. Horiuchi, and R. Yanagimachi, "Effects of light on development of mammalian zygotes," Proceedings of the National Academy of Sciences of the United States of America, vol. 104, no. 36, pp. 14289-14293, 2007.

[6] G. G. Leoni, I. Rosati, S. Succu et al., "A low oxygen atmosphere during IVF accelerates the kinetic of formation of in vitro produced ovine blastocysts," Reproduction in Domestic Animals, vol. 42, no. 3, pp. 299-304, 2007.

[7] H. N. Ciray, T. Aksoy, K. Yaramanci, I. Karayaka, and M. Bahceci, "In vitro culture under physiologic oxygen concentration improves blastocyst yield and quality: a prospective randomized survey on sibling oocytes," Fertility and Sterility, vol. 91, no. 4, pp. 1459-1461, 2009.

[8] E. Kasterstein, D. Strassburger, D. Komarovsky et al., "The effect of two distinct levels of oxygen concentration on embryo development in a sibling oocyte study," Journal of Assisted Reproduction and Genetics, vol. 30, no. 8, pp. 1073-1079, 2013.

[9] J. J. P. Gille and H. Joenje, "Cell culture models for oxidative stress: superoxide and hydrogen peroxide versus normobaric hyperoxia," Mutation Research/DNAging, vol. 275, no. 3-6, pp. 405-414, 1992. 
[10] L. Liu and D. L. Keefe, "Cytoplasm mediates both development and oxidation-induced apoptotic cell death in mouse zygotes," Biology of Reproduction, vol. 62, no. 6, pp. 1828-1834, 2000.

[11] L. Liu, J. R. Trimarchi, and D. L. Keefe, "Involvement of mitochondria in oxidative stress-induced cell death in mouse zygotes," Biology of Reproduction, vol. 62, no. 6, pp. 1745-1753, 2000.

[12] E. Cebral, I. Carrasco, D. Vantman, and R. Smith, "Preimplantation embryotoxicity after mouse embryo exposition to reactive oxygen species," Biocell, vol. 31, no. 1, pp. 51-59, 2007.

[13] S. Yu, H. Long, Q.-F. Lyu et al., "Protective effect of quercetin on the development of preimplantation mouse embryos against hydrogen peroxide-induced oxidative injury," PLOS ONE, vol. 9, no. 2, article e89520, 2014.

[14] C. Velez-Pardo, A. T. Morales, M. J. D. Rio, and M. OliveraAngel, "Endogenously generated hydrogen peroxide induces apoptosis via mitochondrial damage independent of NF- $\kappa \mathrm{B}$ and p53 activation in bovine embryos," Theriogenology, vol. 67, no. 7, pp. 1285-1296, 2007.

[15] N. Igosheva, A. Y. Abramov, L. Poston et al., "Maternal dietinduced obesity alters mitochondrial activity and redox status in mouse oocytes and zygotes," PLoS ONE, vol. 5, no. 4, article e10074, 2010.

[16] C. E. Redon, A. J. Nakamura, Y.-W. Zhang et al., "Histone $\gamma \mathrm{H} 2 \mathrm{AX}$ and poly(ADP-ribose) as clinical pharmacodynamic biomarkers," Clinical Cancer Research, vol. 16, no. 18, pp. 45324542, 2010.

[17] A. Li, Y. Yu, S.-C. Lee, T. Ishibashi, S. P. Lees-Miller, and J. Ausió, "Phosphorylation of histone H2A.X by DNA-dependent protein kinase is not affected by core histone acetylation, but it alters nucleosome stability and histone H1 binding," The Journal of Biological Chemistry, vol. 285, no. 23, pp. 17778-17788, 2010.

[18] V. Turinetto and C. Giachino, "Survey and summary multiple facets of histone variant H2AX: a DNA double-strandbreak marker with several biological functions," Nucleic Acids Research, vol. 43, no. 5, pp. 2489-2498, 2015.

[19] J. Xiao, Y. Liu, Z. Li et al., "Effects of the insemination of hydrogen peroxide-treated epididymal mouse spermatozoa on $\gamma \mathrm{H} 2 \mathrm{AX}$ repair and embryo development," PLoS ONE, vol. 7, no. 6, Article ID e38742, 2012.

[20] B. Wang, Z. Li, C. Wang et al., "Zygotic G2/M cell cycle arrest induced by ATM/Chk1 activation and DNA repair in mouse embryos fertilized with hydrogen peroxide-treated epididymal mouse sperm," PLoS ONE, vol. 8, no. 9, article e73987, 2013.

[21] Y. Song, Z. Li, B. Wang, J. Xiao, X. Wang, and J. Huang, "Phospho-Cdc25 correlates with activating G2/M checkpoint in mouse zygotes fertilized with hydrogen peroxide-treated mouse sperm," Molecular and Cellular Biochemistry, vol. 396, no. 1-2, pp. 41-48, 2014.

[22] D. Deckbar, P. A. Jeggo, and M. Löbrich, "Understanding the limitations of radiation-induced cell cycle checkpoints," Critical Reviews in Biochemistry and Molecular Biology, vol. 46, no. 4, pp. 271-283, 2011.

[23] T. Tanaka, H. D. Halicka, X. Huang, F. Traganos, and Z. Darzynkiewicz, "Constitutive histone H2AX phosphorylation and ATM activation, the reporters of DNA damage by endogenous oxidants," Cell Cycle, vol. 5, no. 17, pp. 1940-1945, 2006.

[24] E. Mladenov, S. Magin, A. Soni, and G. Iliakis, "DNA doublestrand-break repair in higher eukaryotes and its role in genomic instability and cancer: cell cycle and proliferation-dependent regulation," Seminars in Cancer Biology, vol. 37-38, pp. 51-64, 2016.
[25] H. Li, J. R. Mitchell, and P. Hasty, "DNA double-strand breaks: a potential causative factor for mammalian aging?" Mechanisms of Ageing and Development, vol. 129, no. 7-8, pp. 416-424, 2008.

[26] N. T. Bain, P. Madan, and D. H. Betts, "The early embryo response to intracellular reactive oxygen species is developmentally regulated," Reproduction, Fertility and Development, vol. 23 , no. 4, pp. 561-575, 2011.

[27] Z.-F. Peng, S.-L. Shi, H.-X. Jin et al., "Impact of oxygen concentrations on fertilization, cleavage, implantation, and pregnancy rates of in vitro generated human embryos," International Journal of Clinical and Experimental Medicine, vol. 8, no. 4, pp. 6179-6185, 2015.

[28] N. Guo, Y. Li, J. Ai, L. Gu, W. Chen, and Q. Liu, “Two different concentrations of oxygen for culturing precompaction stage embryos on human embryo development competence: a prospective randomized sibling-oocyte study," International Journal of Clinical and Experimental Pathology, vol. 7, no. 9, pp. 6191-6198, 2014.

[29] Y. Zhang, D. Qian, Z. Li et al., "Oxidative stress-induced DNA damage of mouse zygotes triggers G2/M checkpoint and phosphorylates Cdc25 and Cdc2," Cell Stress and Chaperones, vol. 21, no. 4, pp. 687-696, 2016.

[30] A. R. Langley, J. C. Smith, D. L. Stemple, and S. A. Harvey, "New insights into the maternal to zygotic transition," Development, vol. 141, no. 20, pp. 3834-3841, 2014.

[31] J. Van Blerkom, H. Cox, and P. Davis, "Regulatory roles for mitochondria in the peri-implantation mouse blastocyst: possible origins and developmental significance of differential $\Delta \psi \mathrm{m}$," Reproduction, vol. 131, no. 5, pp. 961-976, 2006.

[32] Q. Luo, J. Yang, Q.-L. Zeng, X.-M. Zhu, Y.-L. Qian, and H.-F. Huang, "50-Hertz electromagnetic fields induce gammaH2AX foci formation in mouse preimplantation embryos in vitro," Biology of Reproduction, vol. 75, no. 5, pp. 673-680, 2006.

[33] X. F. Mu, X. L. Jin, M. M. J. Farnham, Y. Li, and C. O'Neill, “DNA damage-sensing kinases mediate the mouse 2-cell embryo's response to genotoxic stress," Biology of Reproduction, vol. 85, no. 3, pp. 524-535, 2011.

[34] Y. Eliezer, L. Argaman, M. Kornowski, M. Roniger, and M. Goldberg, "Interplay between the DNA damage proteins MDC1 and ATM in the regulation of the spindle assembly checkpoint," The Journal of Biological Chemistry, vol. 289, no. 12, pp. 81828193, 2014.

[35] J. An, Y.-C. Huang, Q.-Z. Xu et al., "DNA-PKcs plays a dominant role in the regulation of $\mathrm{H} 2 \mathrm{AX}$ phosphorylation in response to DNA damage and cell cycle progression," BMC Molecular Biology, vol. 11, article 18, 2010.

[36] L. Wang, W. Dai, and L. Lu, "Osmotic stress-induced phosphorylation of $\mathrm{H} 2 \mathrm{AX}$ by polo-like kinase 3 affects cell cycle progression in human corneal epithelial cells," The Journal of Biological Chemistry, vol. 289, no. 43, pp. 29827-29835, 2014.

[37] R. N. Fernando, B. Eleuteri, S. Abdelhady, A. Nussenzweig, M. Andäng, and P. Ernfors, "Cell cycle restriction by histone H2AX limits proliferation of adult neural stem cells," Proceedings of the National Academy of Sciences of the United States of America, vol. 108, no. 14, pp. 5837-5842, 2011.

[38] V. Turinetto, L. Orlando, Y. Sanchez-Ripoll et al., "High basal $\gamma \mathrm{H} 2 \mathrm{AX}$ levels sustain self-renewal of mouse embryonic and induced pluripotent stem cells," STEM CELLS, vol. 30, no. 7, pp. 1414-1423, 2012.

[39] C. Cui, X. Ren, D. Liu et al., "14-3-3 epsilon prevents G2/M transition of fertilized mouse eggs by binding with CDC25B," BMC Developmental Biology, vol. 14, no. 1, article 33, 2014. 
[40] C. Liu, Y. Liu, Y. Liu et al., "Ser 15 of WEE1B is a potential PKA phosphorylation target in G2/M transition in one-cell stage mouse embryos," Molecular Medicine Reports, vol. 7, no. 6, pp. 1929-1937, 2013.

[41] B. Yu, Y. Wang, Y. Liu et al., "Protein kinase A regulates cell cycle progression of mouse fertilized eggs by means of MPF," Developmental Dynamics, vol. 232, no. 1, pp. 98-105, 2005. 


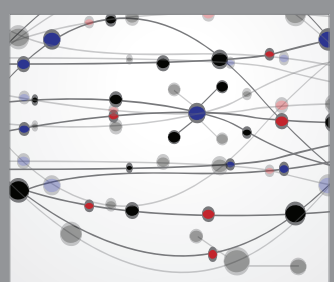

The Scientific World Journal
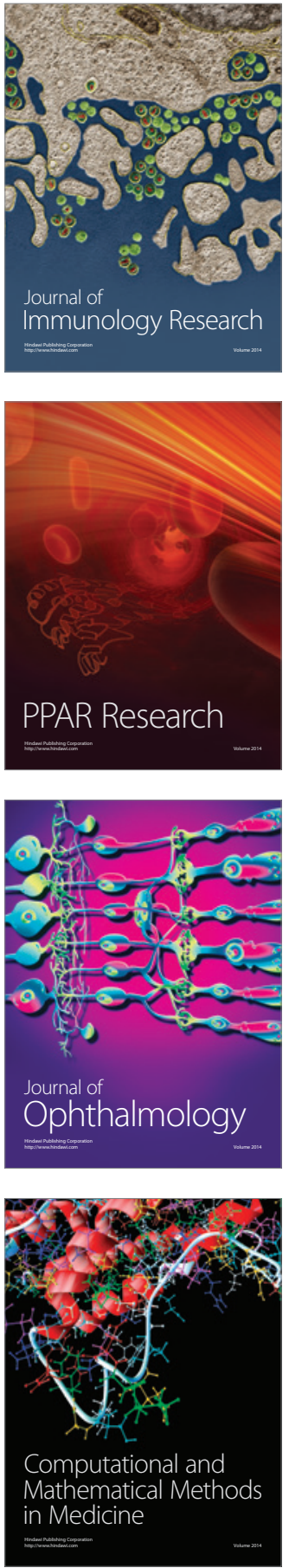

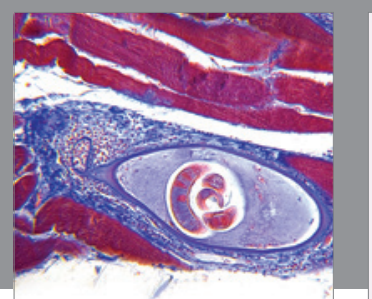

Gastroenterology Research and Practice

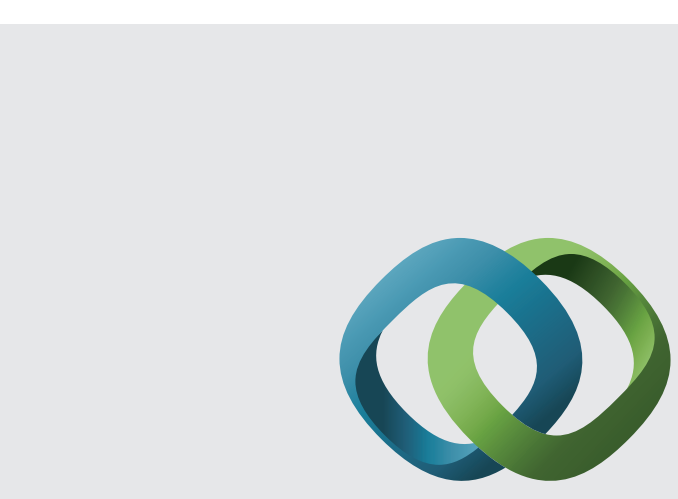

\section{Hindawi}

Submit your manuscripts at

http://www.hindawi.com
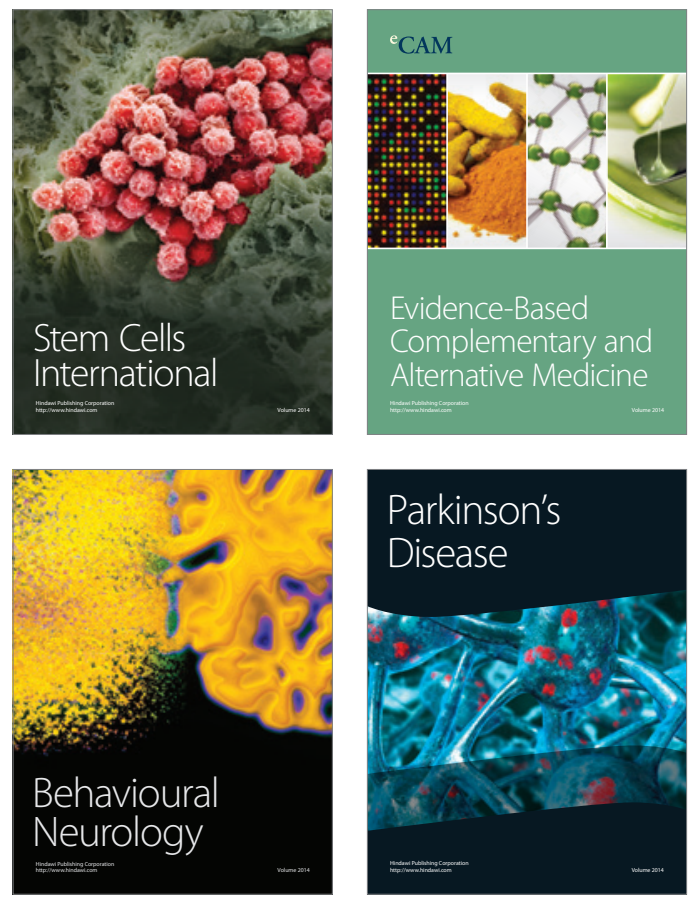
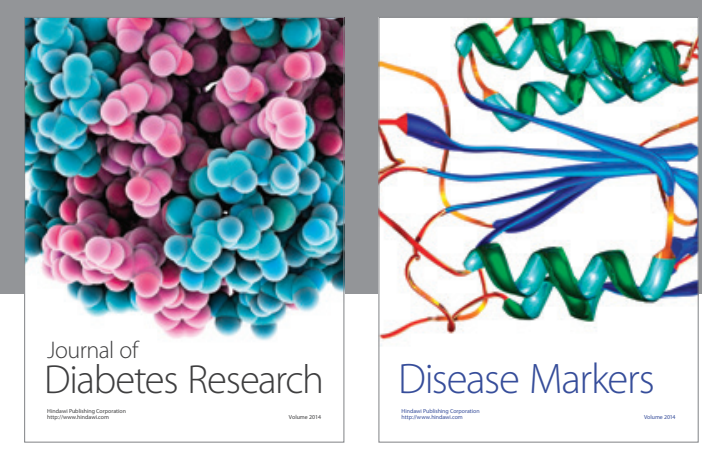

Disease Markers
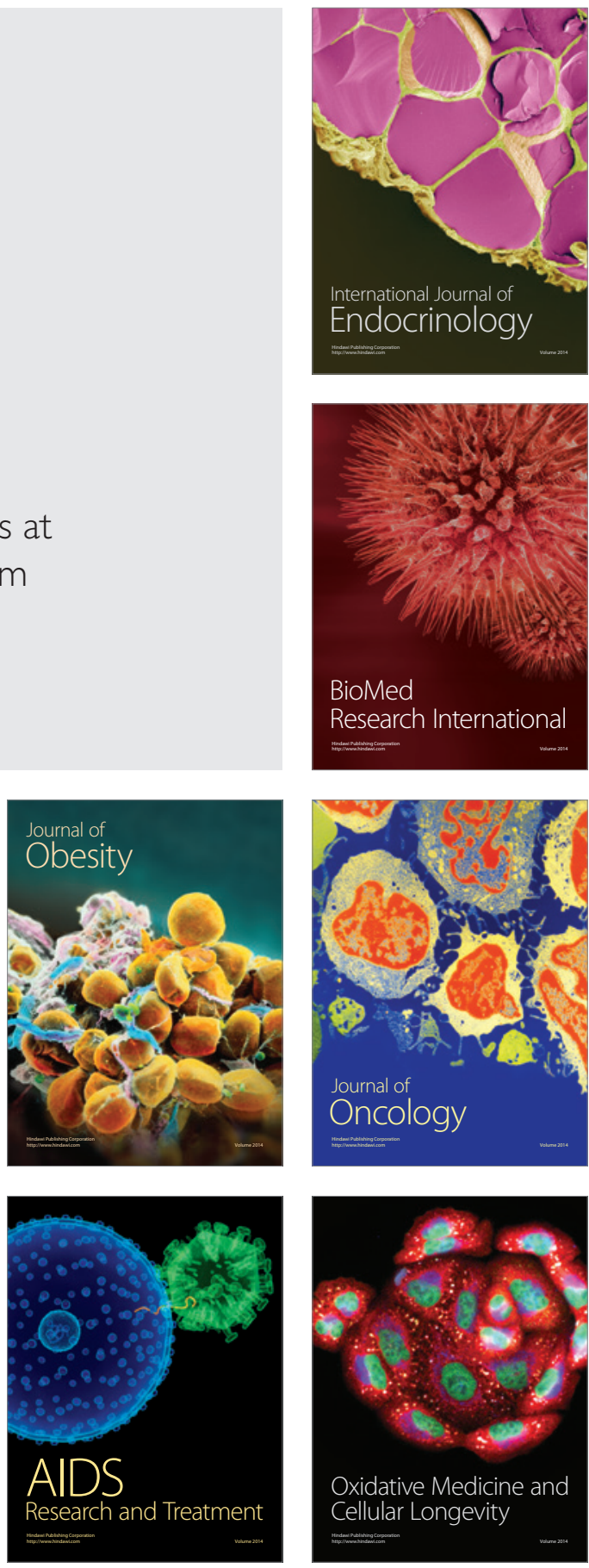